\title{
「はこぶ」技術の低炭素化を 実現する都市システム
}

Urban System for "Carrying” Technology with Low Carbon
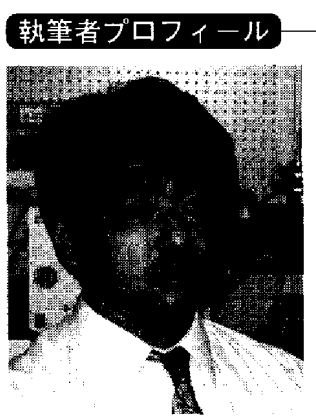

\section{谷川 民生}

Tamio TANIKAWA

口1991 年東京理科大学理工学部電気工学科卒業, 1993 年筑波大学理工学研究科修士課程修了

口主として行っている業務・研究

ユビキタスロボティクス，センサーネットワー ク, マイクロメカニズム

口所属学会および主な活㲜

日本譏掝学会、計测自勤制御学会、日本ロボッ 卜学会, IEEE

口勤務先

正員，(独）産業技術総合研究所知能システ 么研究部門 主任研究買

(下305-8568 茨城県つくば市梅国 1-1-1つく ば中央2 /E-mail : tamio.tanikawa@aist.go.jp)

\section{1.はじめに}

わが国は、「世界全体の温室効果力゙ ス排出量を現状に比して2050 年ま でに半減する」という長期目標を，国 際的に共有することを提案しており，

「低炭素社会」というキーワードとと もにさまざまな取り組みが進みつつあ る.「低炭素社会」における「はこぶ」 という範儔では電気自動車の普及が今 後重要な取り組みとなっている

現在，各目動車メ一力を中心にバッ テリーの開発が進んでおり, ガソリン 車と同等な走行距離を実現する電気自 動車を目指している，しかし，充電施 設など社会インフラ整備も含め、ユー ザが安心して長距離を走行できるよう になるには時間がかかると思われる.
一方，電気自動車は近距離の乗り物之 割り切り，その利用において，ユーザ に対して情報的な支援を行うことで実 用的に利用できる方法も考えられてい る. 具体的には，バッテリーの状態を 常に監視することで, 目的地までの高 低差情報や渋滞状況等，街の環境情報 に基づき，現在位置からどこまで移動 できるか，移動できない場合は，どの 場所で充電が必要かといった，従来の カ一ナビによる地図情報支援をさらに 高度にした情報支援を組み合わせるこ とで実用性の向上を目指している。 す なわち，今後電気自動車は，外界の情 報をネットワークを介してやりとりす るネットワーク端末としての機能が必 要とされる. 電気自動車がネットワー ク端末としての機能を有するために は，交通システムならびにその都市自 体がネットワークを有することで各施 設が有機的につながつていく社会的な 仕組みが必要となる。

「低炭素社会」における「都市のネッ トワーク化」というと「スマートグリッ ド」が挙げられる.「スマートグリッド」 とは，賢い送配電網を通信，IT技術 を組み合わせることで実現しようとす るもので, 風力, 太陽光など元来不安 定な電力供給設備を従来の電力設備と 合わせ，平滑化し，化石燃料の節約と 温暖化ガス排出量の削減を目指すとい うものである：ここでも電気自動車の 役割が重要となっている. 電気自動車 のバッテリーは，一つの大きな蓄電池 であり，今後増えるであろう太陽光発 電や風力発電といつた供給が不安定な 自然エネルギーを，バッテリーという バッファを介すことで, 電力供給の平 滑化に寄与できると考えられている. すなわち，スマートグリッドと電気自 動車はネットワーク網につながること で，双方が補完しあうことができ，社
会全体として低炭素社会に大きく寄与 することが可能となる.

このように「低炭素社会りにおける 「はこぶ」技術は，電気自動車の高度 化だけでなく，電気自動車を取り巻く 都市全体の関係も重要になると考えら れる.

\section{2. コンパクトシティ構 想}

電気自動車が都市を網羅するネット ワーク網を組み合わせることで，電気 自動車の実用性の向上ならびに二酸化 炭素排出量削減に寄与することが可能 となる，一方，自動車自体にも多様性 が生まれている。近年，自動車以外の パーソナルなモビリティが発表されて いる. 例えば，セグウェイ（セグウェ イジャパン), Winglet (トヨタ), U3-X (ホンダ) 等である. 現状では 公道を走ることはできないが，今後は 自動車に変わって，より軽量なパーソ ナルモビリティが活躍する可能性が考 えられる. また，現状でも，高齢者や 障害者が利用しているシニアカ一や電 動車いすが普及しており，法整備次第 では，自動車に変わるモビリティとし て普及が期待される。「低炭素」とい う面からしても，一人で乗るためだけ に、従来のガソソン車と同様な $1 \mathrm{t}$ 近 くある電気自動車で移動をすることは 環境負荷が高い，すなわち，より小型 なパーソナルモビリティを利用するこ とは環境負荷低減には有効であり，今 後の低炭素社会に向けてパーソナルモ ビリティの普及は重要であると考えて いる.

このような背景のもと（独）産業 技術総合研究所ではパーソナルモビリ ティ（図 1，2）や環境のネットワー ク化を容易に実現するためのセンサ ネットワーク技術（図 3）を開発して 

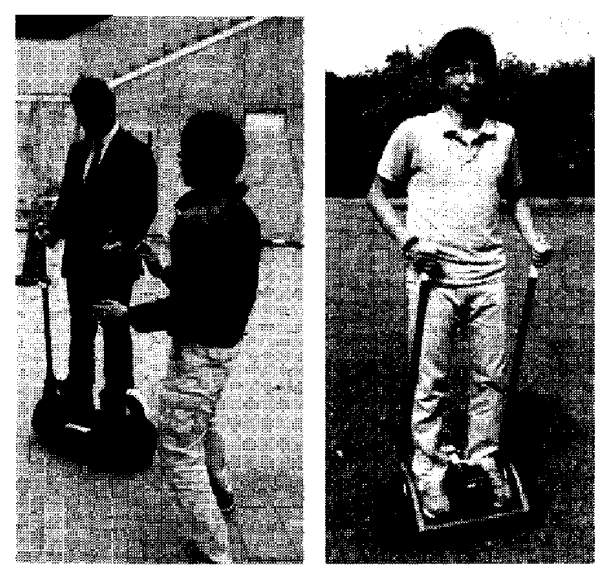

図 1 マイクロモビリティ（PMP-2)

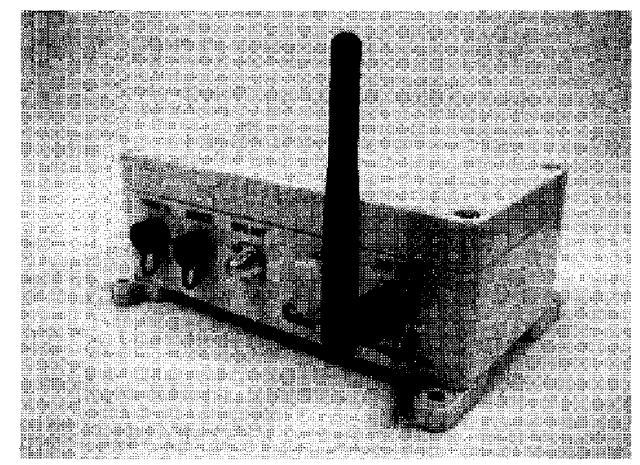

図 3 Zigbee 無線ノード (半径 $1 \mathrm{~km}$ といっ た広範囲の通信が可能）
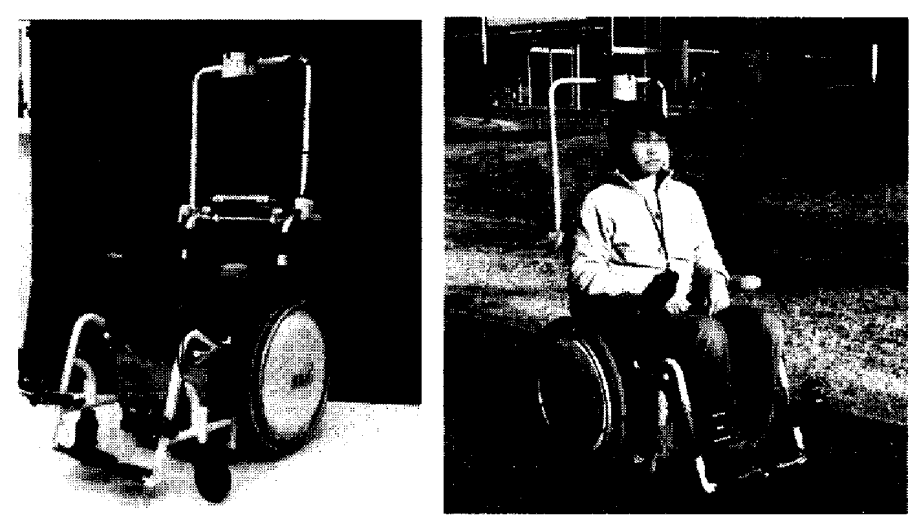

図 2 インテリジェント車いす

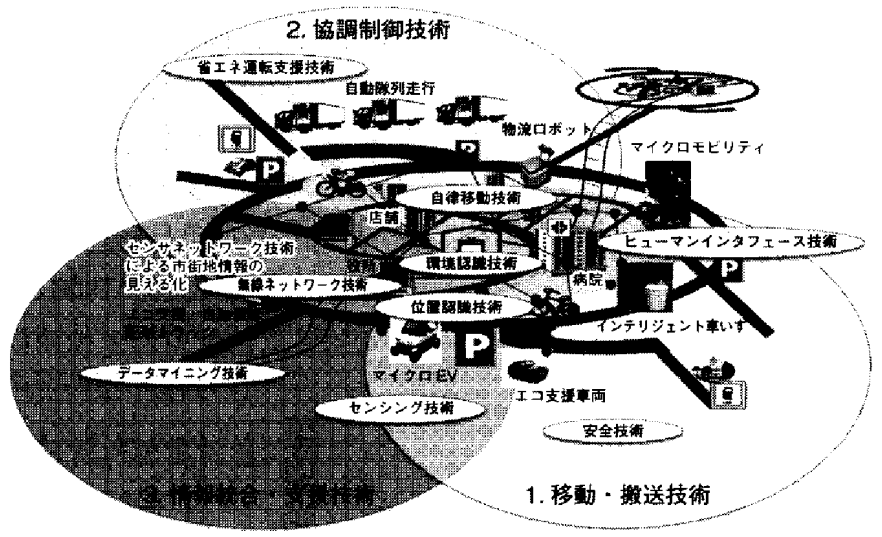

図 4 コンパクトシティ構想
いる.また，それらのロボット技術を 積極的に導入したコンパクトシティ構 想を将来の都市のあり方として提案し ている(图4).コンパクトシティでは, 街の中心市街地では自転車のように手 軽に利用できるパーソナルモビリティ （電動車いす，シニアカーを含む）を 利用し，郊外もしくは他の街に行く交 通手段としては公共交通を利用する。 すなわち，現在は電気自動車普及が環 境負荷低減の一つに挙げられている が，その電気自動車自体が小型化し， 自転車のように手軽に利用できる環境 を整えることで，より環境負荷の低い 低炭素社会が実現できると考えられ る. 一方，自動車の利用は人の移動手 段だけでなく，物流手段としても大い に利用されている.とくに最近では，

インタネットによるネット販売が盛ん になり, 物流の需要は高まっている.

これに対して，現在工場等で利用され ている自動搬送ロボットや自動走行ナ ビゲーション技術を利用し，街全体を 工場内の物流システムと考え, 宅配便 などで自動車を利用している部分を極 力自動化されたロボットを利用し，配 送経路などの効率化を図ることによっ て，環境負荷を低減していく．このよ
うな社会を実現するためには，配送口 ボットといつたロボット本体の開発だ けではその実用化は難しい.すなわち. 交通システムを円滑に運用していくた めの環境インフラの仕組みも重要とな る. 交通システムだけであるならば，

ITS (Intelligent Transportation Systems）等の運用が進められてい るが, コンパクトシティとしては, 電 カネットワークと交通システム, なら びに物流サービスといつたさまざまな システムが連携する必要があり, 街全 体のエネルギ一，交通，物流，人の流 れといった情報の可視化，すなわち「は こぶ」ということを「見える化」する ことが必要となる.「見える化」する ためにはセンサネットワーク技術およ び集められた情報を処理するデータマ イニング技術を導入していく必要があ る. これらの技術を導入することで, 街の環境情報が，それぞれの電力，交 通, 物流システムにフィードバックさ れ, 各システムの相互連携が可能とな り，コンパクトシティが実現可能なも のになっていくと思われる.

このような都市システムの構築には 自治体の協力も重要である，つくば市 では「搭乗型移動支援ロボットの公道
(歩道) 走行社会フィールド実証試験 特区」を国に申請し，2010 年 1 月 29 日に内閣府から認定を受けてい る. 現時点では，実際にどのような実 証実験をしていくかの詳細を固めてい る段階であり，パーソナルモビリティ の実用化ならびに都市システムの実証 実験を後押しする活動として期待され ている.

\section{3. まとめ}

「はこぶ」の低炭素化を実現するた めに，主たる「はこぶ」機能の電気自 動車だけでなく，その電気自動車を有 効に機能させる都市全体の設計として 「コンパクトシティ」を紹介した コ ンパクトシティ構想の中ではさまざま な技術が相互に連携し合い，大きな社 会システムとして運用していかなけれ ばならない.これは、ある分野の企業. 研究機関単体で実現できるものではな く、さまざまな業種の企業，さまざま な分野の研究機関，さらには国，地方 自治体の参加が必要であり，多くの関 係機関の連携が不可欠である。 